Conference Paper

\title{
Analysis of Financial Statements PT. Hanjaya Mandala Sampoerna TBK
}

\author{
Luthfi Widianto Halim*, Rossherleen Clarissa Halim, Imam Setia Permana \\ Nusa Putra University, West Java, Indonesia
}

*Corresponding author:

E-mail: luthfi.widianto_ak19@nusaputra.ac.id

\begin{abstract}
The purpose of this analysis is to know the effect of company profitability on timeliness and effectiveness concerning the progress of a company's financial statements PT. Hanjaya Mandala Sampoerna Tbk from 2016 to 2019. The method used in this research is the quantitative research method and the data obtained in this financial statement is downloaded from the official website of the Indonesia Stock Exchange (IDX). The ratios used are liquidity ratio, solvency ratio, and profitability ratio. Analysis has taken from 2016 to 2019 from liquidity ratio and precisely at the quick ratio, the company was able to pay its short-term debt smoothly despite a decrease in 2019, in previous years the payment of a shortterm debt from the company is fairly smooth so that obligations can be met. But from the solvency ratio of the company PT. Hanjaya Mandala Sampoerna Tbk is less effective in managing the company's wealth/assets, proven from year to year because the Debt to Asset Ratio (DAR) is less than 100\%. For profitability ratio can be seen from the net profit margin has a value of $13 \%$ over 3 years means, the result is more than $10 \%$ then the comparison between price and cost has been well set by looking at the profit results obtained.
\end{abstract}

Keywords: Liquidity ratio, solvency ratio, and profitability ratio

\section{Introduction}

Finance is an important instrument in a company. Every company pays attention to its financial condition, both large and small scale companies. This is due to the development of more advanced and tighter business sectors in the era of globalization. This journal describes the financial statements of PT. Hanjaya Mandala Sampoerna Tbk.

PT Hanjaya Mandala Sampoerna Tbk was chosen because it is a company that has a leading brand in the Indonesian cigarette market. For more than 10 years, Sampoerna led the Indonesian cigarette market with a market share of $32.2 \%$ in 2019. Sampoerna is a subsidiary of PT Philip Morris Indonesia ("PMID") and an affiliate of Philip Morris International Inc. ("PMI"), the leading international tobacco company under the global brand Marlboro. Sampoerna's scope of activities includes the manufacture, trade, and distribution of cigarettes as well as the distribution of Marlboro, the leading international cigarette brand produced by PMID. (https://www.sampoerna.com/sampoerna/id/about-us/overview).

Financial reports are one of the eight instruments to study in evaluating and measuring the company's financial performance because there is important information including financial information about the company's business results and financial position. Every company uses financial reports to see how the company has performed over a certain period. Financial reports have some data in them such as invoices, receipts, credit notes, bank statements, and so on (Kusumo, 2002).

Financial reports help related parties both internally and externally to determine the condition of the company by analyzing financial reports. Financial statement analysis can be done using ratio analysis techniques where there are efforts to develop meaningful relationships between each item in the balance sheet and profit and loss as well as benefit external parties. Analyzing financial statements is intended to find out more information contained in financial statements. From this analysis, it can be seen whether

\section{How to cite:}

Halim, L. W., Halim, R. C., \& Permana, I. S. (2021). Analysis of financial statements PT. Hanjaya Mandala Sampoerna TBK. $1^{\text {st }}$ ICEMAC 2020: International Conference on Economics, Management, and Accounting. NST Proceedings. pages 303-308. doi: 10.11594/ nstp.2021.1035 
all company activities are efficient and effective, or whether the plans and targets set by management have been achieved (O'Connor, 1973).

\section{Literature Review}

Financial statement analysis is used to determine the financial condition of the company being studied, according to Titman \& Keown (2018). In a sense, the analyst conducts financial analysis to see the firm's financial performance through the eyes of an outside investor. The types of financial statements commonly known are balance sheets, income statements, or business results, cash flow statements, reports of changes in financial position.

Brigham \& Houston (2009) divine solvency ratio by the ratio used to measure the extent to which the company's assets are financed with debt. This means that the debt burden is borne by the company compared to its assets. Solvency Ratio consists of: Total Debt to Assets, Total Debt Equity, Long Term Debt to Equity Ratio, and Times Interest Earned Ratio

Profitability Ratio according to Brigham \& Houston (2009) is the company's ability to earn profit about sales, total assets, and own capital. Thus, long-term investors will be very interested in this profitability analysis. Profitability Ratio consists of Profit Margin, Gross Profit Margin, Net Profit Margin, Return on Investment, and Return on Assets.

O'Connor was the first to study the strength relationship ratio in finance (1973). He looked at financial ratios to see if there was a link between finance and stock returns in the future. O'Connor investigates whether financial ratios based on publicly available financial data are useful to external decision-makers. The findings revealed that the evidence provided a solid foundation for analyzing the relationship between variations in the ratio-rate of return model projecting doubt the usefulness of the ratio finance for common stock investors.

\section{Hypothesis}

According to research and study of ratio theory in financial statements have benefits as a comparison material and financial data analysis materials contained in the post-financial statements

\section{Material and Methods}

The type of research used is a quantitative method which is the data collected in the form of absolute figures from financial statements. Quantitative research method can be interpreted as a research method based on the philosophy of positivism, used to examine a certain population or sample, sampling techniques are generally done randomly, data collection using research instruments, data analysis is quantitative / statistics to test the hypothesis that telaj set. The data used in this study is secondary data. Secondary data from this research is obtained from financial statements downloaded from the official website of www.idx.co.id or can be called the Indonesia Stock Exchange (IDX).

\section{Population}

Of the many industrial populations in Indonesia, in this journal will be taken one of them is the industry engaged in the production and sale of cigarettes.

\section{Sample}

Samples were taken from the population of the cigarette industry, namely PT. Hanjaya Man-dala Sampoerna Tbk (2020).

\section{Research object}

The analysis contained in this journal explained that the object of research is financial statements and profit and loss statements from PT. Hanjaya Mandala Sampoerna Tbk. 


\section{Data collection}

The following table is presented the financial statement ratio consisting of Liquidity Ratio, Solvency Ratio, and Profitability Ratio with average cash Rp 11.723.763.

Table 1. the financial statement ratio consisting of Liquidity Ratio, Solvency Ratio, and Profitability Ratio (2016, 2017, 2018, 2019)

\begin{tabular}{|c|c|c|c|c|}
\hline EXPLANATION & 2016 & 2017 & 2018 & 2019 \\
\hline \multicolumn{5}{|l|}{ LIQUIDITY RATIO } \\
\hline > Quick Ratio & 2,20977236 & 2,4922401 & 2,57542513 & 1,98942714 \\
\hline$>$ Cash Ratio & 0,786528786 & 1,1571453 & 1,76443493 & 1,47872204 \\
\hline$>$ Current Ratio & 5,234131003 & 5,2723302 & 4,30196581 & 3,27609023 \\
\hline > Cash Turnover Ratio & 8,143004682 & 8,452191 & 9,10474657 & 9,04617195 \\
\hline \multicolumn{5}{|l|}{ SOLVENCY/LEVERAGE RATIO } \\
\hline > Debt to Assests Ratio & $20 \%$ & $21 \%$ & $24 \%$ & $30 \%$ \\
\hline > Debt to Equity Ratio & $24 \%$ & $26 \%$ & $32 \%$ & $43 \%$ \\
\hline > Long Term Debt to Equity Ratio (LTDER) & $6 \%$ & $7 \%$ & $7 \%$ & $7 \%$ \\
\hline > Times Interest Earned Ratio (TIER) & $24 \%$ & $23 \%$ & $22 \%$ & $17 \%$ \\
\hline \multicolumn{5}{|l|}{ PROFITABILITY RATIO } \\
\hline$>$ Gross Profit Margin & $25 \%$ & $24 \%$ & $24 \%$ & $25 \%$ \\
\hline$>$ Net Profit Margin & $13 \%$ & $13 \%$ & $13 \%$ & $13 \%$ \\
\hline > Operating Profit Margin & $18 \%$ & $17 \%$ & $17 \%$ & $17 \%$ \\
\hline > Return on Assets (ROA) & $30 \%$ & $29 \%$ & $29 \%$ & $27 \%$ \\
\hline$>$ Return on Equity & $37 \%$ & $37 \%$ & $38 \%$ & $38 \%$ \\
\hline
\end{tabular}

Table 2. the financial statement ratio consisting of Liquidity Ratio, Solvency Ratio, and Profitability Ratio (description)

\section{EXPLANATION}

LIQUIDITY RATIO

$>$ Quick Ratio

$>$ Cash Ratio

$>$ Current Ratio

$>$ Cash Turnover Ratio

SOLVENCY/LEVERAGE RATIO

$>$ Debt to Assests Ratio

$>$ Debt to Equity Ratio

$>$ Long Term Debt to Equity Ratio (LTDER)

$>$ Times Interest Earned Ratio (TIER)

PROFITABILITY RATIO

$>$ Gross Profit Margin

$>$ Net Profit Margin

$>$ Operating Profit Margin

$>$ Return on Assets (ROA)

$>$ Return on Equity

\section{DESCRIPTION}

(Current Assets - Inventory) / Current liabilities

(Cash + Cash Equivalents)/Current Debt

Current Assets / Current Debt

Net sales/average cash

$D A R=$ Total Liabilities $/$ Total Assets

$D E R=$ Total Liabilities $/$ Total Equity

LTDER $=$ Term debt $/$ Total Capital

TIER = Earning before income tax / Interest expense

Gross Profit/Total Sales

Net income after tax/total sales

Net income before tax / total sales

Net income after tax / total assets

Net income after tax/total equity 


\section{Data Analysis}

Liquidity ratio

A ratio that shows a company's ability to meet its financial obligations that must be met immediately, or the ability of the company to meet financial obligations at the time of billing. In this case, several ratio calculations are divided into 4 of them:

\section{Quick ratio}

It is a ratio used to measure a company's ability to use current assets without inventory to pay its short-term debt. The result is 2016 was 2,209 while in 2017 it increased to 2,492. Then in 2018 it rose to 2,575 and dropped to 1,989 in 2019 . This means that the company can pay its short-term debt using current assets without inventory despite the decline.

\section{Cash ratio}

Is the ratio used to make a comparison between the total cash and cash equivalents of a company with its current obligations? The result is 2016 was 0.786 while in 2017 it increased to 1,157 . Then in 2018 it rose to 1,764 and dropped to 1,478 in 2019 . This means that the company demonstrates the ability to meet its short-term obligations and guarantee its current debt.

3. Current ratio

It is an accounting ratio used to measure the company's ability to pay existing debt with current assets. The result is 2016 was 5,234 while in 2017 it increased to 5,272. Then in 2018 it rose to 4,301 and dropped to 3,276 in 2019. Based on the above results, because the value is more than 2, the company may not use current assets or short-term financing facilities efficiently and indicates a problem of working capital management.

4. Cash turnover ratio

It is a comparison between sales and the average amount of cash. The cash turnover ratio serves to measure the level of adequacy of working capital to pay bills and finance sales. The result is 2016 was 8,413 while in 2017 it increased to 8,452. Then in 2018 it rose to 9,104 and dropped to 9,046 in 2019. This means that the higher the cash turnover rate, it will show the high volume of sales of the company's products as well as an indication of the speed of return of working capital embedded in cash and cash equivalents.

\section{Solvency/ leverage ratio}

The ratio where there is a comparison measurement of funds provided by the owner with funds borrowed from the company's creditors. This ratio is intended to measure up how far the company's assets are financed by debt. In this case, several ratio calculations are divided into 4 of them:

1. Debt to assets ratio

It is a debt ratio used to measure the ratio between total debt and total assets. The result in 2016 was $20 \%$ while in 2017 it increased to $21 \%$. Then in 2018 it rose to $24 \%$ and rose to $30 \%$ in 2019 . This means that the higher the DAR value indicated:

- The greater the amount of debt-financed assets

- The smaller the amount of capital-financed assets

- The higher the risk of the company to pay off its long-term liabilities

- The greater the interest expense of the debt that the company must pay

Since the DAR value is less than $100 \%$ in the period 2016-2019, it is said to be less good in the comparison of corporate debt

2. Debt to equity ratio

A financial ratio that represents the relative proportion of equity and debt used to finance the company's assets. The result is 2016 was $24 \%$ while in 2017 it increased to $26 \%$. Then in 2018 it rose to $32 \%$ and rose to $43 \%$ in 2019 . This means that the higher the DER value will cause a higher risk to the company's liquidity but if the ratio value is lower, the higher the amount of funding provided by the company owner. Because the value above shows less than $100 \%$ indicates the company has less debt than capital. 


\section{Long Term Debt to Equity Ratio (LTDER)}

Ratios focused on the company's long-term debt. The long-term debt to equity ratio compares the amount of the company's long-term debt with the equity holders. The results obtained in 2016 were $6 \%$ while in 2017-2019 the result was the same as 7\%. Based on the above value, it can be concluded that the company does not guarantee capital fully as a guarantor of long-term debt, and can be concluded a small risk of loss in the management of the company's operations.

4. Times Interest Earned Ratio (TIER)

It is a ratio whose purpose is to know the size of the company's ability to honor the payment of its debts. This can be calculated as EBIT or EBITDA divided by the total interest expense. The result is 2016 was $24 \%$ while in 2017 it was reduced to $23 \%$. Then in 2018 it is decreasing but not significantly to $22 \%$ and increasingly down to $17 \%$ in 2019 . Based on the value above if the lower the tier ratio value, the smaller the company's ability to pay off the loan interest.

\section{Profitability ratio}

It is a comparison to know the company's ability to earn profit from sales, assets, and equity-based on a certain measurement basis. In this case, several ratio calculations are divided into 5 of them (Jurnal, ID, 2020):

1. Gross profit margin

Is a fixed percentage of income after deducting the direct cost of doing business. The result is 2016 was 25\% while in 2017 and 2018 it was reduced to $24 \%$. Then it rose to $25 \%$ in 2019. The higher the gross profit margin, the better and more efficient it will be to suppress HPP. From the data above can be concluded because the value does not reach $100 \%$ then it can be said to be less good in hpp emphasis management.

\section{Net profit margin}

It is a profitability ratio to assess the percentage of net income earned after deducting tax on income derived from sales. The result from 2016-2019 is 13\%. The data shows the difference between net profit and sales generated. Since the result is more than $10 \%$ it is considered to have been very good in setting product prices and cost control.

3. Operating profit margin

The ratio is used to measure the ability it has to generate operating profit and net sales over some time. The result is 2016 was $18 \%$ while in 2017-2019 it dropped to $17 \%$. This ratio represents the level of profit gained from each rupiah of sales or operating margin. Based on the data above when OPM experienced a decrease, the investment risk that investors will face increases.

4. Return on Assets (ROA)

A ratio that shows a percentage of how profitable the company's assets are in generating revenue. The result is $201630 \%$ 2017-2018 is $29 \%$ and down to $27 \%$ in 2019 . The higher the ROA ratio, the better the company's performance in generating a net profit and making money with less investment.

5. Return on Equity (ROE)

It is a measure of the profitability of the business concerning equity. Since shareholders' equity can be calculated by taking all assets and reducing all liabilities, ROE can also be considered a return on assets minus liabilities. The results obtained in 2016-2017 37\% and 2018-2019 increased by $1 \%$ to $38 \%$. In this case, if the ratio is higher, the better the efficiency of the use of own capital for the company's operations.

\section{Conclusion}

From research taken from financial statements PT. HM Sampoerna by calculating the liquidity ratio that is to know the ability of the company to pay short-term debt obligations, solvency ratio to see the effectiveness of the use of company wealth, profitability ratio tests the level of comparison between the profit earned by the company and sales or assets. And on the company PT. HM Sampoerna this result is relatively good in the management of the company's financial and operational statements. 


\section{References}

Brigham, E. F., \& Houston, J. F. (2009). Fundamentals of financial management. USA (US): Cengage Learnin

Jurnal.ID. (2020). Jenis-jenis rasio keuangan. [Internet]. [diakses 2020 November 18]. Tersedia pada: https://www.jurnal.id

Kusumo, W. K. (2002). Analisis rasio-rasio keuangan sebagai indikator dalam memprediksi potensi kebangkrutan perbankan di Indonesia. [tesis]. Semarang (ID). Universitas Diponegoro

O'Connor, M. C. (1973). On the usefulness of financial ratios to investor in common stock. Accounting Review,4, 339-352.

PT HM Sampoerna Tbk. (2020). Tentang sampoerna. [Internet]. [diakses 2020 November 18]. Tersedia pada: https://www.sampoerna.co

Titman, S., Keown, A. J., \& Martin, J. D. (2018). Financial management: Principles and applications. USA (US): Pearson Education Limited. 